\title{
THE INFLUENGE OF COLLECTIVE BARGAINING ON TEACHERS' SALARIES IN NEW YORK STATE
}

\author{
DAVID B. LIPSKY and JOHN E. DROTNING
}

$\mathrm{W}$ Hat impact, if any, has teacher unionism had on teachers' salaries? Others have asked this question, buc to date research results have been inconsistent. ${ }^{1}$ In part, this may be attributed to different research designs and methods; but whatever the reasons for the

This study tests a model of teacher salary determination with data describing several aspects of all school districts in New York state, outside of New York City. The authors find that collective bargaining is not significant in explaining variations in 1968 teacher salaries among all school districts, but bargaining did have a significant effect among small districts and on the rate of salary change from 1967 to I968. On the whole, however, the authors conclude that the results of this and other studies show that bargaining has had a suprisingly minor effect on teacher salaries.

David B. Lipsky is an Associate Professor, and John E. Drotning is a Professor and Associate Dean, in the New York State School of Industrial and Labor Relations, Cornell University. This study was sponsored by the New York State Public Employment Relations Board under authority of the Taylor Law. The authors express 'their gratitude to Thomas $\mathbf{E}$. Joyner, Director of Research for PERB, and Joseph B. Phillips, Assistant Director of Research, for their advice and assistance. The authors, however, retain full responsibility for the analysis and conclusions. Nothing in this article should necessarily be considered the official position of PERB or any of its employees. The authors would like to thank the following people for their research assistance: Archie Campbell, Terry Mulchahey, Alan Glassman, John Eagan, Fred Green, and Michael McManus. They also thank their colleague, Lewis Perl, who offered valuable advice and criticism at every stage of the research, and Frank Mclaughlin of Boston College, who read and commented on an earlier draft of the paper.-EDIror inconsistencies, the relationship between teacher unionism and salaries is not yet completely clear. ${ }^{2}$

This paper analyzes the influence of collective negotiations on teacher salaries in New York state in the first year in which the Taylor Law, governing public employer-mployee relations, was in ef-

I Four principal studies have been published during the past three years. They are, Hirschel Kasper, "The Effects of Collective Bargaining on Public School Teachers' Salaries," Industrial and Labor Relations Review, Vol. 24, No. 1 (October 1970), pp. 57-72; Robert N. Baird and John $H$. Landon, "The Effects of Collective Bargaining on Public School Teachers' Salaries: Comment," Indtusiral and Labor Relations Review, Vol. 25, No. 3 (April 1972), pp. 410-416; Robert]. Thornton, "The Effects of Collective Negotiations on Teachers' Salaries," Quarterly Review of Economics and Business, Vol. 11, No, 4 (Winter 1971), Pp. $37-46$; and W. Clayton Hall and Norman E. Carroll, "The Effects of Teachers' Organizations on Salaries and Class Size," Industrial and Labor Relations Review, Vol. 26, No. 2 (January 1973), pp. 834-841. See also, Hirschel Kasper, "On the Effect of Collective Bargaining on Resource Allocation in Public Schools," Economic and Business Bulletin, Vol. 23, No. 3 (Spring-Summer 1971), pp. 1-9.

2 Three significant studies that deal with determinants of teacher salaries (but not with the effect of collective bargaining) are Hensy $M$. Levin, "A Cost-Effectiveness Analysis of Teacher Selection," Journal of Human Resources, Vol. 5 , No. 1 (Winter 1970), pp. 24-33; John D. Owen, "Toward a Public Employment Wage Theory: Econometric Evidence on Teacher Quality," Industrial and Labor Relations Review, Vol. 25 , No. 2 (January 1972), pp. 219-222; and John $H$. Landon and Robert N. Baird, "Monopsony in the Market for Public School Teachers," American Economic Review, Vol. 6], No. 5 (December 1971), pp. 966-971. 
fect. ${ }^{3}$ Many economists believe that the union's impact on wages is likely to be greatest in the initial stages of organization. More than forty years ago, Paul Douglas concluded,

Unionism, in other words, very probably does give an appreciable increase in earnings during the early period of effective organiza. tion, but during the later and more mature years of union development, the relative rate of further progress seems, to say the least, to be no more rapid on the whole for unionists than for non-unionists.

Thus, the passage of the Taylor Law in 1967 presents a unique opportunity for a study of the type undertaken here. Most New York school districts entered bargaining for the first time in the spring of 1968. Information for 696 dis. tricts reveals that about 63 percent signed collective agreements in 1968. All but a handful had never been organized for bargaining before the passage of the Taylor Law. ${ }^{5}$

Did New York districts with collective bargaining contracts in 1968 have signifi. cantly higher salaries than districts without contracts? Did organized districts win larger salary increases than districts not yet organized? In answering these basic questions, this study also sheds

a For a thorough discussion of the Taylor Law, see Walter E. Oberer, Kurt L. Hanslowe, and Robert E. Doherty, The Taylor Act Amendments of 1969: A Supplemental Primer for School Personnel (And Other's Interested in Collective Negotiations) (Ithaca, New York: New York State School of Industrial and Labor Relations, 1970).

4 Paul H. Douglas, Real Wages in the United States, 1890-1926 (Boston and New York: Houghton Miffin Co., 1930), p. 564.

5 New York City is not included in this study. New York City is obviously exceptional in many ways. For example, although only one of more than 700 districts in the state, it has more than one quarter of all pupils enrolled in the state and spends approximately 30 percent of all money expended on primary and secondary pub. lic education. light on other factors that influence the determination of teacher salaries.

\section{Preliminary Analysis}

Table 1 shows differences in salary levels between districts with contracts in 1968-69 (441) and districts without contracts (255). Teachers are normally paid according to a salary schedule based on two factors: years of experience and college credit hours earned beyond the bachelor's degree. Data were gathered for three salary points in the schedule for each New York district: (I) the salary paid to first-year teachers with only a bachelor's degree (Base or BS minimum); (2) the salary paid to a teacher with seven years of experience and thirty hours of earned credit beyond the bachelor's degree (BS +30 , 7th Step); and (3) the salary paid to a teacher with eleven years of experience and sixty hours of earned credit beyond the bachelor's degree (BS $+60,11$ th Step) .

These three salary points give a representative picture of the salary schedule in each district. "Note that these salary figures may not represent the average salary actually paid in any given district, for that depends on the placement of teachers within the schedule, i.e., the characteristics of the specific teacher work force in terms of experience and earned credits. Yet the use of the teacher salary scale is particularly appropriate, since this is normally the subject of direct negotiation in collective bargaining.

In addition, however, information was obtained on the mean salary actually

\footnotetext{
a For some purposes, the Public Employment Relations Board uses these points as a shorthand for describing a given teacher salary schedule. In a sense, these points describe a "normal" career path for a teacher.
} 
Table 1. Difference in Salary Levels Between New York School Districts with and without Collective Bargaining Contracts, 1968-69.

\begin{tabular}{|c|c|c|c|c|c|}
\hline \multirow{3}{*}{ Salary Level } & \multicolumn{2}{|c|}{$\begin{array}{l}\text { Distritts with Contrats } \\
\quad(N=44 I)\end{array}$} & \multicolumn{2}{|c|}{$\begin{array}{l}\text { Distincts without Contracts } \\
(\mathcal{N}=255)\end{array}$} & \multirow{3}{*}{$\begin{array}{c}\text { Percenlage } \\
\text { Difference } \\
\text { (1) }-(3) \div(3) \\
(5)\end{array}$} \\
\hline & & Standard & & Standard & \\
\hline & $\begin{array}{c}\text { Mean } \\
(I)\end{array}$ & $\begin{array}{l}\text { Deviation } \\
\quad(2)\end{array}$ & $\begin{array}{c}\text { Mean } \\
(3)\end{array}$ & $\begin{array}{l}\text { Deviations } \\
\qquad(4)\end{array}$ & \\
\hline Base salary & $\$ 6,485$ & $\$ 275.9$ & $\$ 6,420$ & f 299.1 & 1.01 \\
\hline BS $+30,7$ th step & 9,091 & 615.8 & 8,943 & 652.0 & 1.65 \\
\hline BS $+60,11$ th step & 10,931 & $1,166.0$ & 10,691 & $1,016.5$ & 2.24 \\
\hline Mean salary & 8,539 & $1,093.6$ & 8,385 & $1,190.4$ & 1.84 \\
\hline
\end{tabular}

paid in each district in 1968.7 Average salaries are not likely to be the direct subject of collective negotiations, but they are a measure of actual compensation received by teachers and therefore are useful in judging the real economic benefit of unionism.

In previous studies, both salary scales and mean salaries have been analyzedbut never in the same study. The differences between the two types of measure are important: later, it will be shown that, in certain respects, the determinants of the salary scale are different than the determinants of average salary.

Table 1 indicates that there were indeed differences in salaries at all levels between districts with and without contracts. This, however, does not take one very far. First, the salary differences be. tween districts are not very large: from about one percent (\$65) at base to 2.24 percent $(\$ 240)$ at the BS +60 , 11th Step. Second, of course, we are not controlling for any other variables influencing teacher salaries.

It is possible, for example, that organized districts had always been higher. paying districts and that high salaries lead to organization, rather than the reverse. In fact, it is true that districts or-

7 Unfortunately, we were not able to obtain mean salary figures for all districts in earlier years. ganized in 1968 had tended to pay higher salaries in 1967 than unorganized districts, but these differences in 1967 were much smaller than those existing in 1968 , ranging from $\$ 25$ at base to $\$ 125$ at the BS +60 , 11th Step. This implies that unionism did produce salary gains for teachers in 1968, as Table 1 suggests, but clearly this hypothesis needs a more rigorous testing that allows for the effect of other determinants of teacher salaries.

\section{A Model of Salary Determination for Public School Teachers}

In a perfectly competitive labor market-where there are no barriers to worker mobility, and workers and employers possess no monopoly power with respect to wages-workers in the same occupation, possessing the same level of skill and having all other relevant characterístics (experience, age, sex, etc.) in common, should receive the same wage. Intraoccupational wage differentials will exist if any of the above conditions are not met. For example, similar jobs may involve different levels of effort with different employers. Second, the assumption of a homogeneous labor supply is usually violated in the real world. Workers possess different levels of skill and experience, and wage levels can be 
expected to reflect these differences. Third, workers are not optimally mobile; movement is not without cost. Moreover, workers may also be tied to their jobs by nonwage considerations, such as preferences for certain work settings, satisfaction with present work associations, etc. Fourth, other market imperfections may also exist. Employers may not be "price takers"; rather they may possess some monopsony power. Workers may also exercise monopoly power. Different market structures will cause wage differences to occur within the same occupation.

The model used in this study to explain differences in teacher salaries is derived from these considerations. One must first consider the fact that "teaching" involves different duties in different districts, so the quality of the position will vary. The pupil-teacher ratio $(P / T)$ is one measure of difference in the quality of jobs available to teachers. Although there may be better measures, differences in average class size are common indicators of quality differences in schools. ${ }^{8}$

The use of $P / T$, however, can be perilous. As Hall and Carroll have pointed out, teachers often bargain just as hard for class size limitations as for higher salaries." Salaries and pupilteacher ratios may be determined simul. taneously through bargaining. Nevertheless, $P / T$ will be used as an independent

8 The "quality" of a school has been measured by student achievement test scotes, percentage of college entrants, and similar indices. See William E. Barron, "Measurement of Educational Productivity," in Warren E. Gauerke and Jack R. Childress, eds., The Theory and Practice of School Finance (Chicago: Rand McNally \&. Co., 1967), Pp. 279-309. The pupil-teacher ratio may be more subject to control by school administrators than other quality indices.

9 Hall and Carroll, "The Effects of Teachers" Organizations on Salaries and Class Size." variable in the analysis, because in the first year of bargaining under the Taylor Law, class size was not a major issue. Even in 1970, according to the New York State Teachers Association (NYSTA), only 255 districts in New York had contracts containing any sort of class size provision, and the great majority of these were simple statements of intent that were not binding on the school district. ${ }^{10}$

In another sense, class size is a double. edged variable: Kasper, for example, implicitly considers $P / T$ a measure of teacher productivity. ${ }^{11}$ If a low $P / T$ is an indication of a high-quality district, one would expect a negative relationship between $P / T$ and salaries. On the other hand, if one expects a correlation between salaries and physical productivity, as measured by class size, then there should be a positive relationship between $P / T$ and salaries. In addition, if teachers prefer smaller to larger classes, the relationship might be positive, indicating that teachers are compensated for the disutility of larger workloads.

Another measure of difference in the quality of districts may be the district's enrollment. Total enrollment, $E$, may reflect both differences in quality and differences in market structures, as Kasper has pointed out. ${ }^{12}$ Larger districts may have more specialized programs (art, music, special education, etc.) requiring teachers of higher skill levels. Larger districts, especially those in the affluent suburbs, may have brighter stu.

10 New York State Teachers Association, Information Service Memorandum, November 30, 1970.

11 Kasper, "On the Effect of Collective Bargaining on Resounce Allocation in Public Schools."

12 Kasper, "The Effects of Collective Bargaining on Public School Teachers' Salaries," p. 69. 
dents and conduct more enriched programs. Moreover, larger districts are likely to be in or near metropolitan areas where competition for teachers may be keen. Conversely, smaller districts may have more monopsony power, because, as Kasper puts it, "There may be no nearby school districts to stimulate competition." 13 Thus, we expect there to be a positive relation between enrollment, $E$, and salaries.

At the same time, one does not expect district size and salaries to be linearly related. This is partly based on Kasper's finding of an "urban turnaround." 14 In the very largest urban school districts, teachers may need skills less of a pedagogic than of a disciplinary variety. Moreover, large city school districts may need to compete more intensely with other public services (welfare, transportation, sanitation, etc.) for a piece of the taxpayer's dollar. ${ }^{15}$

It might be argued that teachers prefer to work in smaller districts, and, therefore, larger districts must pay higher salaries to entice teachers away from preferred smaller districts. Disutilities may result from working in larger districts because of a more impersonal atmosphere, the encumbrances of a large bureaucracy, and disciplinary problems. Many of the larger districts in New York state, however, are subur. ban communities offering highly attractive working conditions much coveted by teachers. If disutilities result in higher salaries, the highest salaries should be found in central city districts that reputedly have the least attractive jobs. Consequently, the expected "urban turnaround" would not materialize.

13 Ibid.

14 Ibid.

15 Ibid.

\section{Salary Schedule and Teacher Characteristics}

The next elements of our model relate to differences in teacher characteristics. Districts differ in the mix of teachers on their staffs. Salary schedules usually require districts to pay higher salaries to teachers with more experience or more earned college credits; therefore, one would expect a positive relation between, for example, mean salary and the per-. centage of teachers in a district with advanced degrees (Master's or better); this variable will be labeled $A D V$.

Some interesting questions arise, how. ever, when one considers the relation between points on the salary schedule and teacher characteristics. For example, does a district with a high $A D V$ necessarily have a high base salary? The hypothesis here is that a district desiring high-quality teachers (as measured by $A D V$ ) will tend to pay high salaries at every point in the salary schedule in order to recruit and retain high-quality teachers, regardless of degree level.

The teacher experience variable tested in our model is the percentage of teachers in a district with three years of seniority or less (SEN 3). This form is chosen for several reasons. For example, it can be argued that districts that recruit heavily (and thus have a high $S E N$ 3) will tend to shift the entire salary schedule upward in order to attract young teachers not only by a high base salary but by the promise of substantial increments throughout their careers, especially since the full cost impact of this shift will not be felt imme. diately. Districts with low salary schedules may suffer from high turnover. Since younger workers are usually the most mobile, high turnover may result in a 
low $S E N 3 .^{16}$ Hence, $S E N 3$ and salaries would be positively correlated.

On the other hand, one would not expect a positive relation between salaries actually paid by districts (for example, mean salaries) and $S E N 3$, because of the requirements of the salary schedule. A district with a teaching staff with extensive experience will necessarily tend to pay higher actual salaries (as opposed to salaries listed in the schedule). Therefore, it is expected that mean salary and $S E N 3$ will be negatively related.

The preceding discussion highlights the possible uses of a teacher salary schedule. A district can adjust a schedule to show, for example, relatively high salaries at the base level but relatively low salaries at subsequent steps. If the district's teachers are employed mainly at the higher steps and no hiring is being done, the average salary actually paid by the district will tend to be lower than other districts with, possibly, a lower base salary but a different agedistribution of teachers. Thus, the common practice of using the base salary as a comprehensive index of a district's average salary level can be quite misleading. ${ }^{17}$ Both administrators and teacher organizations can manipulate the salary schedule to serve various pur. poses-public relations, politics, recruiting, etc.

Some degree of monopsony is likely to exist in teacher labor markets. ${ }^{18}$ As

16 For an analysis of the relationship between turnover and the seniority clistribution of employed workers, see, Vladimir Stoikov, "The Effect of Changes in Quits and Hires on the Length-of-Service Composition of Employed Workers," British Journal of Indtustrial Rela. tions, Vol. 9, No. 2 (July 1972), pp. 225-233.

17 Baird and Landon use only the base salary in their two studies.

${ }_{18}$ This is true because a public school system obviously does not operate in a competitive prod- pointed ont above, the enrollment variable is likely to pick up some monopsony effects. In addition, a dummy variable, $D W N$, is added to the model to capture additional monopsony effects. ( $D W N$ takes a value of $l$ if a district is in downstate New York, 0 otherwise.) Approximately one quarter of the state's districts are in the three downstate counties, Nassau, Suffolk, and Westchester. ${ }^{11}$ An apparently substantial salary differential, favorable to downstate teachers, has persisted in New York state over many years. There may be several reasons for this differential. The argument presented here is that the competitive market structure in the downstate counties is responsible for a large part of the differential. The down. state districts are geographically more concentrated than New York's upstate districts. It is conceivable that a teacher living downstate can change jobs (and districts) many times without changing his place of residence. Most teachers living upstate who change jobs must also necessarily change residences. This means that the downstate teacher is potentially more job-mobile than the upstate teacher, and this gives the upstate district a monopsonistic edge in the labor market.20

uct market but has a virtual monopoly on the provision of educational services within a given geographic area. Thus, teachers are limited in the number of employers with whom they may deal. The most explicit discussion of the mo. nopsony question is in Landon and Baird, "Monopsony in the Market for Public School Teach. ers."

10 Arguably, Rockland might also be considered a downstate county. Since it has only nine districts, its inclusion or exclusion does not affect the analysis to any great extent.

othis is a generalization that probably does not hold for the Buffalo metropolitan area. There are forty-one districts in western New York (Erie and Niagara Counties) competing for teacher services. The next largest upstate county, Monroe (Rochester), has eighteen districts. 
In addition, downstate districts must compete for teachers in a labor market that affords teachers many more opportunities outside the teaching profession than are available in upstate New York. In summary, the downstate market for teachers is likely to be significantly more competitive than the upstate market. ${ }^{21}$

There are other possible, but less plausible, causes of the downstate differ. ential. First, downstace districts tend to be wealthier than upstate districts, and, thus, their ability to pay higher salaries is greater. Wealth variables will be in. corporated into the model. ${ }^{22}$

Second, consumer prices are higher in the downstate area than upstate, and teacher salaries may reflect differences in living costs, but recent research indicates that is unlikely. ${ }^{23}$ Also, there does not appear to be enough variation in the cost of living between upstate and downstate communities to produce the sizable downstate salary advantage.

Third, some argue that strong teacher organizations in the downstate area, particularly in New York City, generate patterns that have lifted the salaries of all downstate districts, both organized and unorganized. Later, this study will correct for some of the pattern-spillover effects that apparently do exist in

21 Landon and Baird argue that the (log of the) number of districts per county is directly related to the competitiveness of the teacher labor market. Since the downstate New York counties have, by far, the highest number of districts apiece in the state, $D W N$ can be viewed simply as a dichotomized version of the Landon and Baird variable. See, Landon and Baird, "Monopsony in the Market for Public School Teachers," pp. 967-969.

2e Although there is a positive correlation between $D W N$ and the wealth variable considered here (true value per pupil), it is not high enough to cause a problem of multicollinearity.

$2 s$ Owen, "Toward a Publc Employment Wage Theory: Econometric Evidence on Teacher Quality," p. 216. teacher bargaining, and it will be seen that our results do not support the contention that a few strong organized districts lift the salaries of all districts in the area. Also, this argument would be more persuasive if the downstate differential had not existed in the prebargaining era, as it clearly did.

Thus, the downstate advantage is probably the result of the more com petitive labor market conditions in that area, and, any analysis of teacher salaries in New York should allow for this differential.

\section{The Regression Models}

The first variant of the model tested is completed by the addition of a union variable, $C T R C T$, which takes a value of 1 if a district had a contract for the year $1968-69$, and 0 otherwise. ${ }^{24}$

In summary, the first model tested takes the form:

$$
\text { (1) } \begin{aligned}
S= & b_{0}+b_{1}(\boldsymbol{P} / T)+b_{2} E-b_{3} E^{2} \\
& +b_{4} A D V+b_{5} S E N 3 \\
& +b_{6} D W N+b_{7} C T R C T+e
\end{aligned}
$$

$S$ is the salary variable; $e$ is the error term; and the other variables have pre. viously been defined. Note that the preceding discussion leads to some uncertainty concerning the signs of $b_{1}$ and $b_{5}$. Essentially, this first model consists of structural characteristics $(P / T, E, D W N)$, teacher characteristics $(A D V, S E N$ ) $)$, and the contract variable.

A second, extended version of the model is also reported here. Added to Equation 1 are variables representing the district's ability to pay and its willingness to pay. A common and accepted measure of ability to pay is "true value

\footnotetext{
24 Approximately 70 districts engaged in some form of negotiations in 1968 but did not sign contracts.
} 
per pupil" $(T V / P) .{ }^{2 s}$ True value is an estimate (admittedly, often a poor one) of the market value of the property in a school district. Since school revenues are based primarily on local property taxes, the value of a district's property wealth behind each pupil is considered a good index of ability to pay.

There is generally less agreement on the appropriate index for a district's willingness to pay. David B. Ross has suggested, "An idea of the effort a community has made to supply public services comes from comparing its ability to pay, measured by its taxable resources, and the amount of tax revenues which actually have been collected and spent on services." ${ }_{26}$ Following Ross's lead, this study considers the ratio of current expenditures to true value a useful measure of a district's "willingness to pay" or "effort." ${ }^{27}$ Current expenditures are defined as instructional costs $(I C)$, and the following identity is noted:

$$
\frac{I C}{P} \equiv \frac{T V}{P} \cdot \frac{I C}{T V}
$$

25 Charles S. Benson, The Economics of Public Education, 2d ed. (Boston: Houghton Mifflin Co., 1968), p. 111. Other labels for the same concept are "full value," "fair value," "fair market value," and "actual value,"

26 David B. Ross, "The Arbitration of Public Employee Wage Disputes," Industrial and Labor Relations Review, Vol. 23, No. 1 (October 1969), p. 6. For further discussion, see John E. Drotning and David B. Lipsky, "The Outcome of Impasse Procedures in New York Schools Under the Taylor Law," Arbitration Journal, Vol. 26, No. 2, 1971, Pp. 95-99.

27 Landon and Baird. "Monopsony in the Market for Public School Teachers," pp. 968969 , use the "effective property tax rate" as their measure of willingness to pay. This is sometimes called "tax on true," and is equal to property tax revenue divided by true value $(x 1,000)$. Thus, the difference between our measure of "effort" and Landon and Baird's is a question of the relation of instructional costs to property tax revenue. For example, in 1969 in New York, property revenue was approximately $\$ 2.1$ million and instructional costs were $\$ 2.6$ million.
Hence, it can be argued that the level of instructional costs per pupil reflects both a district's ability and its willingness to pay. It might be noted that the simple correlation between $T V / P$ and $I C / T V$ is insignificant for New York school districts and slightly negative $(r=-.086)$. Nevertheless, it is hypothesized that both $T V / P$ and $I C / T V$ will have a positive influence on salaries.

The final variable tested in the extended version of the model is debt service per pupil $(D E B T / P)$. The addition of $D E B T / P$ gives a more comprehensive picture of the true costs of educating a district's pupils. ${ }^{28}$ School districts are limited, for the most part, to using borrowed funds for capital ex. penditures. It is expected that $D E B T / P$ will have a positive influence on teacher salaries. Two reasons are suggested for this relation. First, a district with a high $D E B T / P$ is likely to have undertaken a school building program in the recent past. New buildings may result in a higher quality system or an expanded system, both results calling for additional teachers and thus being likely to have a positive influence on salaries. Second, to the extent that new buildings are financed with borrowed funds rather than current tax revenues, the amount of tax revenue available for teacher salaries is not diminished, at least in the short run.

The hypothesis is that a high $D E B T / P$ indicates a system that is growing or being improved, and this creates upward pressure on salaries. Obviously, the ex-

28 The sum of $I C / P$ and $D E B T / P$, however, does not equal total expenditures per pupil. Omitted are items such as expenses related to the board of education and central administration, building maintenance expenses, and "undistributed" expenses, $I C / P$ and $D E B T / P$ combined average about 80 percent of total ex. penditures per pupil. 
istence of debt service in a district's budget may reflect borrowings made many years in the past. Yet, given the rapid acceleration of both construction costs and interest rates in the $1960 \mathrm{~s}$, a high $D E B T / P$ almost inevitably reflects recent bond issues.

The extended model takes the form:

$$
\begin{aligned}
S= & b_{0}+b_{1}(P / T)+b_{2} E-b_{3} E^{2} \\
& +b_{4} A D V+b_{b} S E N 3 \\
& +b_{6} D W N+b_{7} C T R C T \\
& +b_{8}(T V / P)+b_{9}(I C / T V) \\
& +b_{10}(D E B T / P)+e
\end{aligned}
$$

The extended model adds variables denoting the district's costs of producing a student, i.e., the "price of the product." The first model, then, is built on assumptions about the operation of the labor market, and the second adds "product" market variables.

\section{Regression Results}

Results from cross-sectional analyses of the two models, using data from almost 700 New York state school districts, are displayed in Table 2 . In general, the models test out well. About 45 to 60 percent of the variance in the de. pendent variables is explained. Note that the addition of the three financial or "product" market variables does not add much to the $R^{2}$. In fact, for each of the three points from the salary schedule, about one percentage point is added to the variance explained; for mean salary, about three percentage points are added to $R^{2}$. On the other hand, the coefficients of the three financial variables are, for the most part, significant and operate in the expected direction. Teacher salaries do appear to depend on both the dis trict's ability and willingness to pay. $D E B T / P$ is significant in all cases. True value per pupil and $D E B T / P$ are particularly significant in the case of mean salary. Every $\$ 1,000$ increase in $T V / P$ adds $\$ 8$ to average salary. $A \$ 1.00$ increase in debt service per pupil is associated with an increase of $\$ 1.80$ in average salary. The willingness to pay variable, $I C / T V$, has a significant impact on the salary scale, but it apparently plays no role in determining mean salaries. $A$ district's willingness to pay must be determined through the political process. Community political preferences are apparently more likely to be reflected in the salary schedule than in average salaries paid.

Note also that the pupil-teacher ratio, $P / T$, is positively and significantly related to mean salaries, but negatively and insignificantly related (except for BS +60 , 11th Step) to the salary scale. An extra pupil per teacher adds about eighty dollars to average salary and, in a sense, this is a reward for higher productivity. On the other hand, high salary schedules are generally associated with low $P / T$ ratios. If $P / T$ is a measure of quality, it is reflected in the salary schedule, not in terms of salaries actually received by teachers. One can infer from these results that districts with high student-faculty ratios tend to have low salary schedules but older teachers.

Enrollment has the expected relation to the salary scale but not to average salary. Salaries in the schedule increase with district size but at a diminishing rate. The highest salaries at the $\mathbf{B S}+60$, 11th Step, for example, seem to be asso. ciated with districts with about 25,000 pupils. At about 50,000 pupils, the net effect of enroliment on salaries is zero. ${ }^{20}$ This is an example of the turnaround effect. At lower steps in the salary scale,

29 Aside from New York City, the only district with more than 50,000 pupils is Buffalo. 
Table 2. Regression Coefficients for Determinants of Teacher

Salaries in New York State, 1968.

\begin{tabular}{|c|c|c|c|c|c|c|c|c|}
\hline \multirow{3}{*}{$\begin{array}{l}\text { Independent } \\
\text { Variable }\end{array}$} & \multicolumn{8}{|c|}{ Dependent Variable } \\
\hline & \multicolumn{2}{|c|}{ Base Salary } & \multicolumn{2}{|c|}{$B S+30,7$ th Siep } & \multicolumn{2}{|c|}{$B S+60$, llth Step } & \multicolumn{2}{|c|}{ Mean Salary } \\
\hline & Basic Model & Extended Model & Basic Model & Extended Model & Basze Model & Extended Model & Bostc Model & Extended Model \\
\hline$P / T$ & $\begin{array}{c}-2.780 \\
(2.388)\end{array}$ & $\begin{array}{r}-2.969 \\
(2.381)\end{array}$ & $\begin{array}{c}-9.902 \\
(7.160)\end{array}$ & $\begin{array}{c}-7.827 \\
(7.215)\end{array}$ & $\begin{array}{c}-15.866 \\
(9.330)^{*}\end{array}$ & $\begin{array}{c}-14.818 \\
(9.320)^{*}\end{array}$ & $\begin{array}{l}79.971 \\
(10.212)^{* * *}\end{array}$ & $\begin{array}{l}83.460 \\
(10.052)^{* * *}\end{array}$ \\
\hline$E$ & $\begin{array}{l}.0142 \\
(.0035)^{* * *}\end{array}$ & $\begin{array}{l}.0137 \\
(.0035)^{* * *}\end{array}$ & ${ }_{(.0073)}^{.0335}$ & $\begin{array}{l}.0332 \\
(.0072)^{* * *}\end{array}$ & $\begin{array}{l}.0539 \\
(.0137)^{* * *}\end{array}$ & $\begin{array}{l}.0557 \\
(.0138)^{* * *}\end{array}$ & $\begin{array}{c}-.0093 \\
(.0150)\end{array}$ & $\begin{array}{c}-.0087 \\
(.0149)\end{array}$ \\
\hline$E^{3}$ & -.0161 & $\begin{array}{l}-.0152 \\
(.0071)^{* *}\end{array}$ & $\begin{array}{l}-.0480 \\
(.0140)^{* * *}\end{array}$ & $\begin{array}{l}-.0464 \\
(.0140)^{* * *}\end{array}$ & $\begin{array}{l}-.1028 \\
(.0279)^{* * * *}\end{array}$ & $\begin{array}{l}-.1042 \\
(.0279)^{* * *}\end{array}$ & $\begin{array}{c}-.0353 \\
(.0305)\end{array}$ & $\begin{array}{c}-.0334 \\
(.0301)\end{array}$ \\
\hline$A D V$ & $\begin{array}{l}1.7431 \\
(.952)^{*}\end{array}$ & $\begin{array}{l}1.6784 \\
(.973)^{*}\end{array}$ & $\begin{array}{l}8.3823 \\
(1.905)^{* * *}\end{array}$ & $\begin{array}{l}7.6405 \\
(1.971)^{* * *}\end{array}$ & $\begin{array}{l}23.441 \\
(3.722)^{* * *}\end{array}$ & $\begin{array}{l}21.560 \\
(3.807)^{* * *}\end{array}$ & $\begin{array}{l}41.280 \\
(4.074)^{* * *}\end{array}$ & $\begin{array}{l}37.545 \\
(4.106)^{* * *}\end{array}$ \\
\hline$S E N 3$ & $\begin{array}{l}.7124 \\
(.8797)\end{array}$ & $\begin{array}{l}.5543 \\
(.8819)\end{array}$ & $\begin{array}{l}7.7724 \\
(1.7995)^{* * *}\end{array}$ & $\begin{array}{l}7.5011 \\
(1.8023)^{* * *}\end{array}$ & $\begin{array}{l}17.093 \\
(3.438)^{* * *}\end{array}$ & $\begin{array}{l}17.214 \\
(3.452)^{* * *}\end{array}$ & $\begin{array}{l}-.1021 \\
(3.763)\end{array}$ & $\begin{array}{l}-.2022 \\
(3.7227)\end{array}$ \\
\hline$D W N$ & $\begin{array}{l}414.58 \\
(25.92)^{* * * *}\end{array}$ & $\begin{array}{l}403.88 \\
(26.79)^{* * * *}\end{array}$ & $\begin{array}{l}842.06 \\
(52.71)^{* * *}\end{array}$ & $\begin{array}{l}806.28 \\
(53.86)^{* * * *}\end{array}$ & $\begin{array}{l}1,157.81 \\
\quad(101.30)^{* * *}\end{array}$ & $\begin{array}{l}1,157.81 \\
(104.87)^{* * *}\end{array}$ & $\begin{array}{l}843.98 \\
(110.88)^{* * *}\end{array}$ & $\begin{array}{l}691.53 \\
(113.10)^{* * *}\end{array}$ \\
\hline CTRCT & $\begin{array}{c}4.951 \\
(17.784)\end{array}$ & $\begin{array}{c}5.523 \\
(17.755)\end{array}$ & $\begin{array}{r}.4888 \\
(36.924)\end{array}$ & $\begin{array}{c}7.953 \\
(36.717)\end{array}$ & $\begin{array}{c}-12.832 \\
(69.497)\end{array}$ & $\begin{array}{l}-2.592 \\
(69.489)\end{array}$ & $\begin{array}{c}3.419 \\
(76.068)\end{array}$ & $\begin{array}{c}6.527 \\
(74.945)\end{array}$ \\
\hline$T V / P$ & & $\begin{array}{c}.0003 \\
(.0005)\end{array}$ & & $\begin{array}{l}.0018 \\
(.0011)^{*}\end{array}$ & & $(.0044$ & & $\begin{array}{l}.0080 \\
(.0021)^{* * *}\end{array}$ \\
\hline$I C / T V$ & & $\begin{array}{l}.0216 \\
(.0088)^{* *}\end{array}$ & & $\begin{array}{c}.0318 \\
(.0169)^{*}\end{array}$ & & $\begin{array}{l}.0569 \\
(.0344)^{*}\end{array}$ & & $\begin{array}{l}.0013 \\
(.0371)\end{array}$ \\
\hline$D E B T / P$ & & $\begin{array}{l}.2743 \\
(.1283)^{* *}\end{array}$ & & $\begin{array}{l}.6934 \\
(.2680)^{* * *}\end{array}$ & & $\begin{array}{l}6951 \\
(.4020)^{*}\end{array}$ & & $\begin{array}{l}1.807 \\
(.5414)^{* * *}\end{array}$ \\
\hline Constant & $6,261,42$ & $6,242,22$ & $8,217,02$ & $8,111,54$ & $8,995.95$ & $8,881.33$ & $5,080.44$ & 4.853 .75 \\
\hline $\begin{array}{l}R^{2} \\
\text { Standard } \\
\quad \text { error of } \\
\text { estimate }\end{array}$ & 198.10 & 196.59 & 396.30 & 392.48 & 774.15 & 769.45 & 847.34 & 829.86 \\
\hline
\end{tabular}

***Significant at $p<.01$

${ }^{*}$ Significant at $p<.05$

*Significant at $p<.10$.

Note: Standard errors are in parentheses. 
however, the turnaround occurs only at an enrollment level that is outside the range of districts included in this study. Large central city districts may be required to pay higher starting salaries to compensate teachers for the disutilities associated with urban schools. More experienced teachers, however, may receive relatively lower salaries in urban districts. This implies that the salary structure in city districts may be more compressed than in outlying, suburban districts.

The variable $A D V$ is significantly related to each of the dependent variables, but particularly to BS +60 , 11th Step and to mean salary. The Beta coefficients (not shown in Table 2) reveal that $A D V$ is the single mosc infuential variable for mean salary, the second most important variable for BS +60 , 11 th Step. A high proportion of teachers with advanced degrees pulls up the entire salary schedule, even base salary. This might be called a reverse bumping effect. Of course, the impact is much greater at the higher steps and greatest in the case of mean salary. An increase of 10 percent. age points in $A D V$ adds an estimated $\$ 375$ to $\$ 413$ to mean salary.

$S E N 3$ is insignificant in the case of base and mean salary. A high proportion of young teachers does appear to be associated with an increase in the higher steps in the schedule. This effect is somewhat unexpected, but not perverse. Perhaps young teachers have long time horizons and are attracted to districts paying higher salaries at the higher steps. A growing district will probably have a high proportion of young teachers, and growth may put upward pressure on all points in the salary scale. ${ }^{30}$

\footnotetext{
30 The simple correlation between $S E N 3$ and $D E B T / P$, however, is only .14.
}

The favorable salary differential enjoyed by downstate districts is quite sub. stantial, even when other variables are controlled for. The $D W N$ differential ranges from about $\$ 400$ at base to $\$ 1,100$ at BS +60 , I Ith Step. To some extent, downstate districts are purchasing more qualified teachers: the simple correlation between $D W N$ and $A D V$ is .61 ; this is the only point in the model at which a problem of multicollinearity exists.

Finally, it is clear that the model's measure of the effects of collective bargaining, CTRCT, has no significant relation to teacher salaries. The small size of the coefficients and the large standard errors indicate that the apparent differences displayed in Table 1 are largely illusory-they are accounted for by other variables.

The evidence from this regression analysis would indicate that collective bargaining has no impact on salaries, but certain factors must be kept in mind in drawing any conclusions. First, the variable CTRCT is certainly not the only, and may not be the best, way of measuring the effects of bargaining. If it were possible, for example, to distinguish between "weak" and "strong" teacher unions, more meaningful results might be obtained. Such distinctions are difficult to draw and were not feasible for this study. Second, and more important, spillover effects may be blurring union impact and these can be corrected for, at least in part.

\section{Spillover Effects}

The existence of genuine collective bargaining in 60 percent of the districts in New York state in 1968 may have heavily influenced salary schedules among the 40 percent that were not effec. tively organized; that is, districts without. 
formal negotiations and contracts may have chosen or been forced to follow the lead of organized districts and set their own salaries as if they were organized. It is well known that patterns are pervasive in public school bargaining. ${ }^{31}$ Unorganized districts may have been just as subject to the leadership of patternsetters as organized districts. Labor market pressures may have forced a district to match what its neighbors were paying or risk being unable to recruit and retain the teachers it needed. Districts wishing to avoid negotiations with a teacher organization may have elected to set salaries in line with comparable organized districts. All of this implies that if spillover effects are significant, the impact of the union will be seriously understated.

If spillover is a problem, how can its effects be corrected for? Assume that the amount of spillover is a function of the geographic proximity of school districts; that is, spillover will be greater among districts that are spatially clustered. A district that is isolated geographically will be relatively immune to pattern effects. The experience of the parties in negotiations provides some prima facie evidence to support this assumption: when comparisons are used as a standard for salary determination, it is inevitably nearby or adjacent districts that are used for the purpose. The more distant the district, the less relevance it has for the parties.

Earlier, it was argued that the spatial concentration of districts is a correlate of labor market competition; that is, spillover and competitiveness go hand-

31 Richard Pegnetter, "Fact Finding and Teacher Salary Dispuces: The 1969 Experience in New York State," Industrial and Labor Relations Review, Vol. 24, No. 2 (January 1971), pp. 226-242. in-hand. In practice, it may be impossible to determine which effect accounts for a given salary pattern.

These considerations suggest a method of correcting for spillover. If a subsample consisting of relatively isolated districts can be selected, the influence of spillover will be reduced, if not eliminated. Furthermore, such a sample would consist of districts operating in less competitive, more monopsonistic labor markets. For example, a sample might be constructed consisting only of small-town districts or districts within a given enrollment range-that is, those relatively uninfluenced by geographically proximate districts and therefore less involved in any "orbit of coercive comparison."

Table 3 presents the results of running the basic model for districts with enrolIments of 1,001 to 2,000 pupils. There are 188 districts in the sample, most of which are small, upstate communities, at some distance from major metropolitan areas. (Only 12 percent are downstate districts.) About 63 percent of these districts were organized in 1968, matching the extent of organization among all districts in the state. These small districts, however, tended to be poorer (the mean $T V / P$ is $\$ 19,800$ ) and to have larger average pupil-teacher ratios $(P / T=22.0)$ than the average district in the state. The willingness ratio, $I C / T V$, also tended to be lower than the average for the state.

The most interesting result shown in Table 3 is the significant effect unionism appears to have on salaries; CTRCT is associated with $\$ 72$ more on base to $\$ 913$ more for BS + 60, 11th Step. In percentage terms, dividing the CTRCT coefficients by the (unweighted) means of each of the dependent variables for dis- 
Table 3. Regression Coefficients for Determinants of Teacher Salaries in New York State Districts with Enrollments of 1,001 to 2,000 Pupils, 1968.

\begin{tabular}{|c|c|c|c|c|}
\hline \multirow[b]{2}{*}{ Independent Variable } & \multicolumn{4}{|c|}{ Dependent Variable } \\
\hline & Base Salary & $\begin{array}{c}B S+30 \\
7 t h \text { Slep }\end{array}$ & $\begin{array}{c}B S+60, \\
\text { Illh Step }\end{array}$ & Mean Salary \\
\hline$P / T$ & $\begin{array}{r}-12.808 \\
(2.897) \ldots * *\end{array}$ & $\begin{array}{r}-34.843 \\
(6.127)^{* * *}\end{array}$ & $\begin{array}{r}-47.956 \\
(9.649)^{* * *}\end{array}$ & $\begin{array}{r}1.9467 \\
(32.815)\end{array}$ \\
\hline$A D V$ & $\begin{array}{l}-6.2310 \\
(2.034)^{* * *}\end{array}$ & $\begin{array}{r}-3.2261 \\
(4.302)\end{array}$ & $\begin{array}{r}.1198 \\
(6.775)\end{array}$ & $\begin{array}{l}32.328 \\
(8.998) * * *\end{array}$ \\
\hline$S E N 3$ & $\begin{array}{r}.1264 \\
(1.529)\end{array}$ & $\begin{array}{c}5.3414 \\
(3.233)^{*}\end{array}$ & $\begin{array}{c}8.6006 \\
(5.092)^{*}\end{array}$ & $\begin{array}{r}-6.4104 \\
(6.763)\end{array}$ \\
\hline$D W N$ & $\begin{array}{l}405.31 \\
(60.09)^{* * *}\end{array}$ & $\begin{array}{l}793.15 \\
(127.08)^{* * * *}\end{array}$ & $\begin{array}{l}\text { I }, 267.71 \\
(200.13)^{* * *}\end{array}$ & $\begin{array}{l}660.05 \\
(265.78)^{* * * *}\end{array}$ \\
\hline CTRCT & $\begin{array}{l}72.116 \\
(28.046) * * * *\end{array}$ & $\begin{array}{l}190.515 \\
(59.315)^{* * *}\end{array}$ & $\begin{array}{l}313.253 \\
(93.410)^{* * *}\end{array}$ & $\begin{array}{c}210.511 \\
(124.057)^{*}\end{array}$ \\
\hline$T V / P$ & $\begin{array}{r}.00059 \\
(.0014)\end{array}$ & $\begin{array}{c}.00185 \\
(.00295)\end{array}$ & $\begin{array}{r}.00217 \\
(.0047)\end{array}$ & $\begin{array}{r}.00380 \\
(.0062)\end{array}$ \\
\hline$D E B T / P$ & $\begin{array}{r}-.1866 \\
(.2256)\end{array}$ & $\begin{array}{c}-.4611 \\
(.4772)\end{array}$ & $\begin{array}{r}-.6924 \\
(.7515)\end{array}$ & $\begin{array}{c}.7159 \\
(.9981)\end{array}$ \\
\hline Constant & $6,885.36$ & $9,447,50$ & $11,134.96$ & $7,192.2 \mathrm{I}$ \\
\hline$R^{2}$ & .522 & .647 & .666 & .488 \\
\hline $\begin{array}{l}\text { Standard error of } \\
\text { estimate }\end{array}$ & 160.43 & 339.30 & 534.34 & 709.65 \\
\hline
\end{tabular}

***Significant at $p<.01$.

* Significant at $p<.05$.

*Significant at $p<.10$.

Note: Standard errors are in parentheses.

tricts in the sample results in the follow. ing:

$\begin{array}{lc}\text { Salary Level } & \text { Percentage } \\ \text { Base salary } & 1.12 \\ \text { BS }+30,7 \text { th step } & 2.15 \\ \text { BS }+60,11 \text { th step } & 2.95 \\ \text { Mean salary } & 2.41\end{array}$

These union differentials are similar to, but slightly higher than, the differentials shown in the third column of Table 1. Of course, in the analysis represented in Table 3, other variables influencing salaries are controlled for, making the results far more meaningful. However, although the CTRCT regression coeffi. cients are significant in a statistical sense, a 2 percent union differential is not likely to affect substantially the allocation of resources within a district. On the other hand, since the test employed here does not entirely eliminate spill- over, the union effect may be understated.

The $R^{2}$ s in Table 3 are also similar to those in Table 2 . There are differences in how the model works with this particular sample. For example, the coeffcients for the financial variables are not significant. Ability to pay and $D E B T / P$ do not appear to influence salary determination in these districts. ${ }^{82}$ If these districts do have greater monopsony power, they have greater discretion in setting salaries, regardless of financial indices of "ability" and "willingness."

It is significant that the $I C / T V$ ratio was lower, on the average, for these districts than for the state as a whole. This implies that the districts were not exert-

\footnotetext{
32 The "willingness" ratio, IC/TV, was tested in earlier runs but was not included in Table
} 8. 
ing themselves to the same extent that other districts, both larger and smaller, were. In a sense, these districts were collecting monopsony rents. Under these circumstances, it is not surprising that collective bargaining appears to be more influential in this sample than elsewhere. Teachers organized for genuine bargain. ing can force monopsonistic districts to behave as price-takers in the labor market, rather than discretionary pricesetters. In this way, the teachers can extricate some of the "economic rent" for themselves. Bargaining forces these districts into bilateral monopoly, in which power factors play a large role. At the same time, spillover effects are reduced, since the districts are scattered and relatively isolated.

It should be noted that the basic model was tested against other subsamples. When run on all districts with 1,000 or fewer pupils $(\mathrm{N}=235$ ), the coefficient for the CTRCT variable, with one exception, was not significant. The one exception was the BS +60 , 11th Step. CTRCT was significant at the .05 level; the coefficient was $\$ 410$, almost 4 percent of the mean salary at that level. At other salary levels, the coefficient ranged from $\$ \$ 2$ to $\$ 149$, but the standard errors were too large to make the results significant.

These small, largely rural districts might be considered to have potentially as much monopsony power as those districts with 1,001 to 2,000 pupils and therefore to present the same prospects for union gains. In 1968, however, only 36 percent of these districts had contracts. Furthermore, in the districts where the teachers had organized, bargaining was largely unsophisticated; the contract was a simple document, seldom more than a few pages in length; and effective control often remained with the board of education. It is probable that, given the rapid extension of bargaining through 1969 and 1970 and the growing sophistication of negotiators on both sides, a strong union effect might be found in the smallest districts if data for 1970 or 1971 were to be tested.

For districts with more than 2,000 pupils, no significant CTRCT variables were discovered-the results being roughly equivalent to those in Table 2 . Furthermore, no significant effects were found when upstate and downstate districts were divided and tested separately.

\section{Changes in Salary Levels, 1967-68}

This section deals with the relation of collective bargaining to salary changes that occurred between 1967 and 1968 . Table 4 shows that teachers who ob. tained collective agreements in 1968 seemed to win larger salary increases than teachers who did not have such contracts. For example, base salary in * creased by an average of $\$ 598$ in districts with contracts in 1968 compared to $\$ 558$ in districts without contracts. Base salary

Table 4. Changes in Salary Levels, 1967-68: Differences Between New York School Districts with and without Collective Bargaining Contracts.

\begin{tabular}{|c|c|c|c|c|}
\hline \multirow[t]{2}{*}{ Salary Level } & \multicolumn{2}{|c|}{$\begin{array}{l}\text { Districts with Contracts } \\
\qquad(N=44 I)\end{array}$} & \multicolumn{2}{|c|}{$\begin{array}{l}\text { Districts without Contracts } \\
\qquad(\mathcal{N}=225)\end{array}$} \\
\hline & Mean & Standard Detzation & Mean & Standard Deviation \\
\hline Base salary & $\$ 598$ & $\$ 211.7$ & $\$ 558$ & $\$ 293.4$ \\
\hline BS $+30,7$ th step & 782 & 297.6 & 704 & 402.2 \\
\hline BS $+60,11$ th step & 986 & 410.2 & 871 & 521.0 \\
\hline
\end{tabular}


Table 5. Regression Coefficients for Determinants of Changes in Teacher Salaries in New York State, 1967-68.

\begin{tabular}{|c|c|c|c|}
\hline Independent Variables & $\begin{array}{l}\text { Change in } \\
\text { Base Salary }\end{array}$ & $\begin{array}{c}\text { Dependent Vartables } \\
\text { Change in } \\
\text { BS }+30,7 t h \text { Siep }\end{array}$ & $\begin{array}{c}\text { Change in } \\
B S+60, \text { Illk Slop }\end{array}$ \\
\hline$E$ & $\begin{array}{c}.0059 \\
(.0043)\end{array}$ & $\begin{array}{l}.0138 \\
(.0060)^{* *}\end{array}$ & $\begin{array}{l}.0247 \\
(.0080)^{* * *}\end{array}$ \\
\hline$E^{*}$ & $\begin{array}{l}.0075 \\
(.0083)\end{array}$ & $\begin{array}{l}-.0019 \\
(.0117)\end{array}$ & $\begin{array}{l}-.0173 \\
(.0156)\end{array}$ \\
\hline$A D V$ & $\begin{array}{l}-3.6752 \\
(1.111)^{* * *}\end{array}$ & $\begin{array}{l}-2.9907 \\
(1.512)^{* *}\end{array}$ & $\begin{array}{r}-.6030 \\
(2.087)\end{array}$ \\
\hline$S E N 3$ & $\begin{array}{l}-2.0562 \\
(1.070)^{* *}\end{array}$ & $\begin{array}{r}-1.0098 \\
(1.510)\end{array}$ & $\begin{array}{l}-.4498 \\
(2.004)\end{array}$ \\
\hline$M A L E S$ & $\begin{array}{l}.2106 \\
(.1259) *\end{array}$ & $\begin{array}{l}.4415 \\
(.1762)^{* *}\end{array}$ & $\begin{array}{l}.5276 \\
(.2360)^{* *}\end{array}$ \\
\hline$D W \mathcal{N}$ & $\begin{array}{l}-12.730 \\
(30.936)\end{array}$ & $\begin{array}{c}-9.652 \\
(43.373)\end{array}$ & $\begin{array}{r}-2.4482 \\
(58.231)\end{array}$ \\
\hline CTRCT & $\begin{array}{l}83.039 \\
(21.573)^{* * *}\end{array}$ & $\begin{array}{l}109.837 \\
(30.259)^{* * *}\end{array}$ & $\begin{array}{l}130.591 \\
(40.660)^{* * * *}\end{array}$ \\
\hline Constant & 655.924 & 624.149 & 582.519 \\
\hline$R^{2}$ & .070 & .063 & .066 \\
\hline Standand error of estimate & 244.10 & 340.53 & 453.77 \\
\hline
\end{tabular}

$* *$ Significant at $p<.01$

* Significant at $p<.05$.

"Significant at $p<.10$.

Note: Standard errors are in parentheses.

averaged $\$ 5,887$ in 1967 in districts that won contracts in 1968; in 1968, the base salary of these districts averaged $\$ 6,485$. In unorganized districts, base salary averaged $\$ 5,862$ in 1967 and $\$ 6,420$ in 1968.

Once again, however, other variables influencing salary changes need to be controlled for. Therefore, the basic model was tested to determine if salary changes, rather than salary levels, might have been influenced by the presence of a collective bargaining contract. The movement of salaries from year to year is probably susceptible to a number of transient and random factors. Short-term changes cannot be explained so neatly by a reasonably compact model of the type used to analyze salary levels. It turned out that factors such as ability to pay, willingness to pay, and average class size were not related to salary changes. The most interesting results of the analysis are shown in Table 5. Although only 6 or 7 percent of the variance in salary changes is explained by the regressions, in each case CTRCT is a highly significant variable.

The results indicate that the presence of a contract added about $\$ 83$ to the amount by which base salary was increased from 1967 to 1968 . The corresponding figures are $\$ 110$ at the BS $+\mathbf{3 0}$, 7 th Step and $\$ 131$ at the BS $+60,11$ th Step. Thus, collective bargaining apparently resulted in salary increases that were approximately 15 percent greater than one would have expected otherwise. $^{33}$

93 If the coefficient, $\$ 83$, is divided by the average increase in base salary in unorganized districts (\$558), the result is 14.8 pencent. At the BS $+30,7$ th Step, dividing $\$ 110$ by $\$ 704$ gives 15.6 percent; at the BS +60 , IIth Step, \$1\$1 divided by $\$ 871$ equals 15.0 percent. 
One variable not previously included in the analysis also appears to have influenced salary changes. $M A L E S$, the percentage of males in a district's teacher work force, had a positive and significant impact on salary clsanges. $A D V$ is significant in two equations in Table 5 , but unexpectedly it was negatively related to the dependent variables. Enrollment, $E$, is positively related to salary changes, and significant in two equations, but $E^{2}$ is not significant. Apparently, there is no urban turnaround effect with respect to salary changes. $D W N$, an important factor in explaining salary levels, is insignificant here.

Given the low $\boldsymbol{R}^{*}$ s and relatively high standard errors of estimate, the equations in Table 5 would not be useful for predictive purposes. Important variables may have been missed, and CTRCT may have captured some of the effects of these omitted variables. Nevertheless, the available evidence suggests that collective bargaining did result in larger negotiated increases in the salary scale than teachers would have gained in the absence of organization.

\section{Comparisons with Other Studies}

Table 6 summarizes the principal studies now available on the influence of collective bargaining on teacher salaries. The table is virtually selfexplanatory, although it provides no justification for the various regression models used by the several authors. In examining the table, one notices that the models have certain common variables. For example, district size is an explanatory variable in three studies. Each study has used an income or wealth variable, usually to serve as a proxy for ability to pay. The pupil-teacher ratio has also been considered by several authors.
A comparison of the conclusions reached through the various studies shows that the union variable was found to be statistically significant in the Thornton and the Hall and Carroll studies, but not significant in Kasper's research. The results are mixed in the study by Landon and Pierce and also in the present study, depending on (1) the dependent variable tested, (2) the specification of the union variable, and (3) the construction of the sample. It is more interesting to compare the range of the union effect in the various studies. Despite other differences, the percentage figures fall mainly into a rather narrow range, hovering between 2 and 4 percent. Kasper, for example, finds that teacher organizations increased average salaries by a maximum of about 4 percent. Landon and Pierce find almost no union effect in two tests but a maximum of 4.9 percent in a third. Thorton finds the effect to be between 1 and 4 percent, except for the "AM maximum" salary level in which the effect is a staggering (and unconvincing) 29 percent. Hall and Carroll's best estimate is just under 2 percent. The largest effect on salary level found in this study is just under 3 percent; without any correction for spillover, the effect is zero.

Thus, additional research has served to reinforce Kasper's initial findings, at least in terms of the magnitude of the union effect. As Kasper put it, "Given these small estimates, it seems unlikely that bargaining has produced a signifi. cant or widespread reallocation of educational resources." 34

At the same time, it is hazardous to predict what the effect of teacher unionism will be in the future. This study's

\footnotetext{
$34 \mathrm{Kasper}$, "The Effects of Collective Bargaining on Public School Teachers' Salaries," p. 71.
} 
Table 6. A Comparison of Studies of the Influence of Collective Bargaining on Teacher Salaries.

\begin{tabular}{|c|c|c|c|c|c|}
\hline \multirow[b]{2}{*}{ Matrix } & \multirow[b]{2}{*}{ Kasper } & \multirow[b]{2}{*}{ Landon \& Pierce } & \multicolumn{2}{|c|}{ Siudy } & \multirow[b]{2}{*}{ Lipsky Gै Drotning } \\
\hline & & & Thornton & Hall \& Carroll & \\
\hline $\begin{array}{l}\text { Unit of } \\
\text { observation }\end{array}$ & $\begin{array}{l}\text { All states (including } \\
\text { D.C.) }\end{array}$ & $\begin{array}{l}\text { School districts with } \\
\text { enrollments of } 25,000 \\
\text { to } 50,000 \text {, all of U.S. }\end{array}$ & $\begin{array}{l}\text { School districts in } \\
\text { cities with more than } \\
100,000 \text { population, all } \\
\text { of U.S. }\end{array}$ & $\begin{array}{l}\text { Elementary school } \\
\text { districts in Cook } \\
\text { County, Illinois }\end{array}$ & $\begin{array}{l}\text { All school districts in New } \\
\text { York state (except New } \\
\text { York City) }\end{array}$ \\
\hline Size of sample & 51 & 44 & 83 & 118 & 696 \\
\hline Year(s) examined & $1967-68$ & $1966-67$ & $1969-70$ & $1968-69$ & $1967-68$ \\
\hline $\begin{array}{l}\text { Significant } \\
\text { independent } \\
\text { variables }\end{array}$ & $\begin{array}{l}\text { Per capita income, } \\
\text { urbanization, per- } \\
\text { centage local revenue, } \\
\text { expenditures per pupil }\end{array}$ & $\begin{array}{l}\text { Number of districts in } \\
\text { area, per capita in- } \\
\text { come, percentage } \\
\text { revenue from local } \\
\text { sources }\end{array}$ & $\begin{array}{l}\text { District size, average } \\
\text { wage in area }\end{array}$ & $\begin{array}{l}\text { District size, median } \\
\text { family income, per- } \\
\text { centage male teachers, } \\
\text { average seniority, } \\
\text { state-aid per pupil as } \\
\text { percentage of per pupil } \\
\text { expenditures }\end{array}$ & $\begin{array}{l}\text { District size, percentage } \\
\text { teachers with advanced } \\
\text { degrees, percentage teachers } \\
\text { with } 3 \text { or fewer years service, } \\
\text { pupil teacher ratio, true } \\
\text { value per pupil, "effort" } \\
\text { ratio, debt service per pupil }\end{array}$ \\
\hline $\begin{array}{l}\text { "Union" } \\
\text { variable(s) }\end{array}$ & $\begin{array}{l}\text { (1) Percentage } \\
\text { teachers represented by } \\
\text { organization, (2) per- } \\
\text { centage of districts with } \\
\text { representation, ( } 3 \text { ) } \\
\text { percentage of teachers } \\
\text { covered by agreements }\end{array}$ & $\begin{array}{l}\text { (1) Dummy variable } \\
\text { (1 = negotiations } \\
\text { held), (2) percentage } \\
\text { teachers members of } \\
\text { NEA, (3) percentage } \\
\text { teachers members of } \\
\text { AFT }\end{array}$ & $\begin{array}{l}\text { Dumny variable }(1= \\
\text { collective bargaining } \\
\text { contract })\end{array}$ & $\begin{array}{l}\text { Dummy variable }(1= \\
\text { collective bargaining } \\
\text { contract) }\end{array}$ & $\begin{array}{l}\text { Dummy variable ( } 1-\text { collec- } \\
\text { tive bargaining contract) }\end{array}$ \\
\hline "Union" effect & $\begin{array}{l}\text { Insignificant-adds } 0 \text { to } \\
\text { about } 4 \text { percent }\end{array}$ & $\begin{array}{l}\text { (1) Dummy variable } \\
\text { significant-adds } \\
\text { about } 4.9 \text { percent } \\
\text { (2) percentage NEA: } \\
\text { barely significant ( } 3 \text { ) } \\
\text { percentage AFT } \\
\text { insignificant }\end{array}$ & $\begin{array}{l}\text { Significant-adds from } \\
2.3 \text { to } 28.8 \text { percent }\end{array}$ & $\begin{array}{l}\text { Significant-adds } \\
\text { about } 1.8 \text { percent }\end{array}$ & $\begin{array}{l}\text { (1) Effect in entire sample } \\
\text { insignificant, (2) effect in } \\
\text { "small town" sample sig- } \\
\text { nificant, (3) effect on salary } \\
\text { change significant. Adds } 0 \text { to } 3 \\
\text { percent to salary levels, } 15 \\
\text { percent to salary changes }\end{array}$ \\
\hline
\end{tabular}


finding that bargaining added about 15 percent to salary increases, although subject to certain caveats, indicates that over time the cumulative effect of teacher bargaining might cause a substantial reallocation of educational resources. If the conclusion reached by Paul Douglas can be applied to the public sector, how. ever, it seeems unlikely that organized teachers can sustain their relative advantage into the indefinite future.

\section{Summary and Conclusion}

This study has been based on a model that makes certain assumptions about the teacher labor market. The model's independent variables included teacher characteristics, structural factors, and financial variables, as well as a dummy variable representing the "bargaining effect." The dependent variables included both mean salary and rates taken from the salary schedule.

The model was first tested against all New York state school districts (excluding those in New York City) for the year 1968, the first year in which the Taylor Law was in effect. Collective bargaining was found to have had no effect on teacher salary levels, regardless of whether the dependent variable was a measure of actual earnings (mean salary) or of scheduled rates.
In an attempt to correct for spillover effects, the model was tested on certain subsamples of New York districts. For districts with enrollments between 1,001 and 2,000 pupils-essentially small town districts-the union effect was positive and significant for both types of salary measure. We argue that these districts were both relatively isolated from spillover and had a certain amount of monopsony power, so that a positive bargaining effect is more likely here than elsewhere.

Finally, estimates were made of the effect of collective bargaining on salary changes from 1967 to 1968 , and the bargaining effect once again was found to be positive and highly significant, adding about 15 percent to salary increases.

Teacher unionism initially came to New York districts in which slightly higher salaries were already being paid. The effect of bargaining in the first year of the Taylor Law was to increase the favorable differential already enjoyed by the newly organized districts. The effect was probably greatest in small town, upstate districts, especially at the higher salary steps. The magnitude of the bargaining effect even at the eleventh step, however, was probably not more than 3 percent. For the state as a whole, without any correction for spillover, the salary effect of teacher unions was not significantly different from zero. 